\title{
Spatial and temporal analysis of forest cover change in Falgore Game Reserve in Kano, Nigeria
}

\author{
Muhammad Sabiu Suleiman", Oliver Vivian Wasonga, Judith Syombua Mbau and Yazan Ahmed Elhadi
}

\begin{abstract}
Introduction: Multi-temporal land-use and land-cover data provides a historical vehicle for determining and evaluating long-term trends in bio-physical landscapes. Land-use and land-cover assessment and mapping is one of the most useful applications of geographic information system (GIS) for planning, management, and development. This study analyses the spatio-temporal pattern of forest cover dynamics for three decades in Falgore Game Reserve in Kano, Nigeria. The dynamics of forest cover transition during 1985-2015 was analysed using multi-temporal Landsat imagery.

Results: The spatio-temporal analysis shows that moderate woodland dominated in 1985 (46\%) and 2005 (57\%) but was replaced by open woodland in 2015 which accounts for 58\% of the total area of Falgore Game Reserve (FGR) currently. Dense woodland occupied the least area of the total forest estate that varied between $17 \%$ in 1985 and $1 \%$ in 2015. The results indicate that dense woodland, moderate woodland, and very open woodland were decreased at annual average rate of 3, 1, and $0.4 \%$. Open woodland had expanded from 21,127 ha in 1985 to 53,392 ha in 2015. The main drivers of forest resource degradation in the area were found to be excessive fuelwood collection, overgrazing, agricultural expansion, and forest fire.

Conclusions: These findings suggest that protection strategies employed in FGR were not effective as deforestation is still evident in the reserve. Government and environmental based NGOs should therefore prioritize effective and efficient conservation strategy for present and future use of forest resources, in addition to the provision of alternative livelihood sources to communities proximate to the reserve. This will ensure the socio-economic well-being of the locals and sustainable conservation of biological diversity in the area.
\end{abstract}

Keywords: Forest, Trend, Game reserve, Falgore, Degradation

\section{Introduction}

The last few decades marked massive changes in land use and land cover in forest ecosystems of Nigeria. These changes were attributed to increase in human population, agricultural expansion, and changes in socioeconomic well-being of the people which have triggered unsustainable extraction of natural resources. Rising in human population and global climate change have been reported to be among the key factors that have contributed to vegetation cover losses and gains in a seasonally dry tropical ecosystems globally (Lambin et al. 2003;

\footnotetext{
* Correspondence: mssabiubuk@yahoo.com

Department of Land Resource Management and Agricultural Technology, University of Nairobi, P.O. Box 29053Loresho Ridge, Nairobi, Kenya
}

Lepers et al. 2005). Forest ecosystems, including tropical deciduous forests and savannas, occupy about $14 \%$ of Earth's terrestrial area $\left(18.6 \times 106 \mathrm{~km}^{2}\right)$ and constitute $15 \%$ of global vegetation carbon stocks (Melillo et al. 2002).

Among nations with the highest deforestation rates, significant proportions of their forest losses have been reported on the savanna woodland forests that are poorly protected (FAO 2010; Green et al. 2013). In Nigeria, for example, forest estate occupies about 10 million ha representing almost $10 \%$ of the total land area $\left(92,377 \mathrm{~km}^{2}\right.$ ) (Usman and Adefalu 2010). The total forest cover is made up of about 445 protected areas, distributed over the five main ecological zones of fresh water/ mangrove, the lowland rainforest, the derived savanna, and the Sahel/Sudan savanna. However, most of these 
forest reserves have been degraded with some not having any forest left (USAID/Nigeria 2008). This is because most of the protected areas lack adequate protection and management, therefore faced with the problems of illegal logging, encroachment by farmers, overgrazing by livestock, and excessive fuelwood collection among other factors. For instance, widespread poaching and encroachment by local people have been reported in the Kainji Lake National park, the Yankari Game Reserve, and the Old Oyo National Park (Oseni 2007; USAID/ Nigeria 2008; Meduna et al. 2009). Similarly, the Wildlife Conservation Society noted that there are over 600 illegal farms within the Afi Wildlife Sanctuary alone (WCS 2010). The problem of inadequate governance and lack of political will to safeguard these nature reserves have negatively impacted on the once flourishing and ecologically diverse forest ecosystem of the state (Meduna et al. 2009).

Falgore Game Reserve which is the main focus of this study is facing numerous natural and human-induced causes of degradation (Badamasi et al. 2010) attributed to illegal exploitation such as felling of trees for fuel, non-timber forest products' (NTFPs) collection such as gum arabic, honey, and medicinal plants, and uncontrolled livestock grazing by herdsmen (Yelwa, 2008). The problems of Falgore Game Reserve (FGR) are more profound when considered on the basis of its potential ecological services to the nation. The reserve provides a unique ecosystem that serves as an important freshwater catchment basin serving Kano, Jigawa, Bauchi, Yobe, and Borno States and Lake Chad, as well as provision of numerous NTFPs for its proximate communities. According to Akinbami (2003) and MEA (2005), Nigeria is among the countries with the highest rate of primary forest loss the world over, with an annual average rate of $5.7 \%$ compared to the world average of $3.3 \%$ per annum. For instance, the natural forest cover in the country had decreased from $25,951 \mathrm{~km}^{2}$ in 1976 to less than $10,114 \mathrm{~km}^{2}$ in 2005 , indicating a loss of about $53 \%$ of the total forestland. Forest ecosystem modifications perpetrated profound negative impacts on sustainable food production, freshwater availability, species diversity and richness, climate, and human well-being (Overmars and Verburg 2005 and Potter et al. 2007). The problems of deforestation in Nigeria's National Parks and forest reserves are largely attributed to inadequate trained staff, lack of equipment, corruption, and poor remuneration among other factors (Meduna et al. 2009).

Understanding the dynamics of these changes is necessary for generating valuable information for better decision making in the management of natural resources $(\mathrm{Lu}$ et al. 2003). This is because changes in land use and land cover have been directly linked to biodiversity loss, climate change, food insecurity, human health, and general environmental degradation (Dunjó et al. 2003 and Heistermann et al. 2006).

As indicated by Wasonga (2009), spatial and temporal identification of changes in social and ecological condition is the key to targeting and prioritizing areas for development interventions. In addition, remotely sensed land-use data provides a historical vehicle for determining and evaluating long-term trends in bio-physical landscapes. Land-use and land-cover assessment and mapping is one of the most useful applications of geographic information system (GIS) technique for planning, management, and development (Wasonga 2009). Yang et al. (2007) reiterates the versatility of remotely sensed data in mapping out environmental degradation trends as a result of human-induced impacts and natural factors such as climate change and wildfire across the globe. At global scale, many studies have used remote sensing and geographic information system techniques to map out environmental changes, for instance, Diouf and Lambin (2001), Wasonga (2009), and Tsegaye et al. (2010) in drylands; Shalaby et al. (2012) in agricultural areas; Mwita et al. (2013) in wetlands; Liu et al. (2012) and Peluso (1995); Satake and Rudel (2007); Redo and Millington (2009); Laurin et al. (2013) in forestlands.

This study was conducted to analyse the spatiotemporal dynamics of forest cover change and the perceived drivers of forest degradation in the area over a period of three decades (1985-2015) using remote sensing techniques. The specific objectives were to map the forest cover types of FGR in 1985, 1998, 2005, and 2015; assess the magnitude and nature of change of various forest cover types during 1985-2015; and determine the drivers of NTFPs degradation in the study area as perceived by the communities.

\section{Forest policy and institutional framework in Nigeria}

The institutions responsible for forest and biodiversity management at both the federal and state levels are coordinated via the National Council on Environment. The National Council on Environment is made up of the Federal Ministry of Environment and State Commissions of Environment. There is, however, no single government agency assigned to coordinate biodiversity conservation in the country. These policy loopholes provide an incentive for indiscriminate resources exploitation virtually in all part of the country. This problem is especially severe in the savannah woodland forest where bush burning and bush fire occurs frequently during the dry season.

Forest conservation and management policies are taking a new dimension the world over with most of the countries adopting complete or partial devolution system of management. However, despite this spring of change in the world forest sub-sector, forest policy and its administrative 
machinery in Nigeria focused on government as the only stakeholder. This is because the framework does not encourage people's participation in forest management, even though it states the need for the private sector participation as part of the strategies to achieve the objective of government policy on forest product. For example, the compulsion of individuals, groups, organizations, and communities to obtain permission from government forestry offices before harvesting any tree, including those raised by them on their own land, suggests that all forest resources belongs to government alone. This policy negatively affects the level of investment of individuals or private organization and, thus, must be carefully reviewed if the twin goal of sustainable natural resource management and livelihoods is to be achieved (Usman and Adefalu 2010).

Moreover, the devotion of the protected areas to partial or strict nature reserves is counterproductive and is denying local community and indigenous people's access to nontimber forest products, which are key to their livelihood. The success of forest resources conservation in Nigeria requires the full integration of social and economic goals into conservation planning process in order to ensure that forest stakeholders' expectations are met. Therefore, sustainable forest resources' conservation under the existing states' natural resource laws and regulations needs to be reviewed to conform to the current realities. Also, resource property rights need to be well defined and properly enforced.

\section{Methods}

\section{Study area}

The study was conducted in FGR, Kano, Nigeria. The FGR formerly known as Kogin Kano Game Reserve is located between longitudes $8^{\circ} 30^{\prime}$ and $8^{\circ} 50^{\prime}$ East and latitudes $10^{\circ}$ $46^{\prime}$ and $11^{\circ} 20^{\prime}$ North, $150 \mathrm{~km}$ south of Kano city (Fig. 1). It has an estimated area of 92,000 ha and borders Tiga artificial Lake to the north and Lame Burra Game Reserve in Bauchi State to the southeast (BirdLife International 2007).
In a normal year, the mean annual rainfall in FGR is estimated at $1000 \mathrm{~mm}$, and this decreases northwards to about $800 \mathrm{~mm}$ around Kano Metropolitan (Olofin 2000). The FGR is a gallery forest with a high density of tree species and high floristic diversity found within the open Northern Guinea Savannah woodland vegetation type, though with elements of the Sudan Savannah in the northern tip (BirdLife International 2007).

The wild natural resources in the game reserve have been dwindling over time. For instance, there was a general decrease in both floral and faunal wild populations between 1990 and 2006. This decrease was attributed to frequent bush burning, lumbering, and hunting Fagge (personal communication August 22, 2014).

The area is characterized by rocks of the basement complex of pre-Cambrian age to the west and south and the Chad formation to the northeast. The first two geomorphological types are part of the high plains of Hausaland while the third is part of the Chad plains (Olofin 2000). According to the 2006 census figures from national population commission of Nigeria, Kano State has a population of 9,383,682 people, therefore the most populous state in the country. The annual population growth rate of the state is $3 \%$ and therefore projected to be 12,198,786 by 2016 (FRN 2010). More than a half of the inhabitants of the area are farmers involved in growing cereals, legumes, and vegetables. In addition to cultivation, livestock rearing and trade are major activities in the state (KNARDA 2006). The major inhabitants of the state are the Hausa and Fulani ethnic groups whose main source of livelihoods is livestock rearing, farming, hunting, and fishing, although hunting and fishing as livelihood activities cause little or no harm to the forest ecosystem if carried out in a conventional way.

\section{Sampling procedure}

Multistage sampling technique was used for this study. Three local government areas (LGAs), namely, Doguwa,

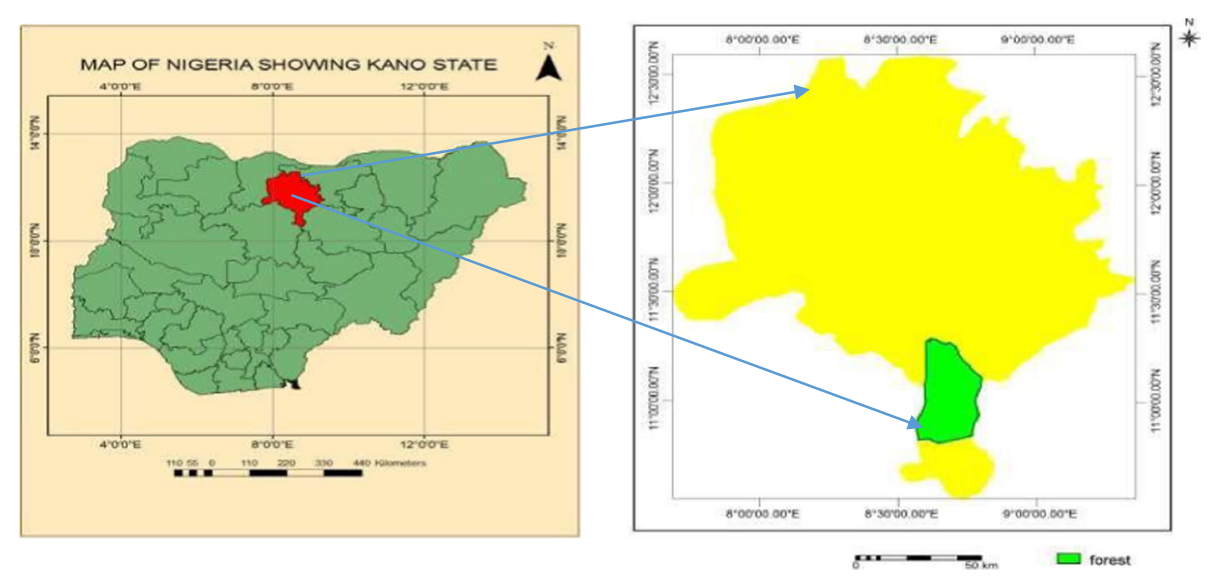

Fig. 1 Study area 
Sumaila, and TudunWada in Falgore Game Reserve area were purposively selected because of the existence of a large portion of the reserve in their territories, as well as the high number of forest-dependent communities in the LGAs. At the second stage, three villages which are directly adjacent to the FGR were purposively chosen from the selected LGAs. Generally, these villages were selected due to their high tendency to largely depend on non-timber forest resources from the reserve. In total, nine villages, namely, Falgore, Yantabarmi, Dogon Kawo, Ziria, Gomo, Diwa, Makwasa, Farurunruwa, and Nufawa were selected for the study.

A formula by Taro Yamana (Glenn 1992) was used to compute the appropriate sample size for the study, taking into consideration the projected number of households of the selected communities. The adoption of this formula is informed by the desire to draw a representative sample from the target population and also to minimize sampling error and bias.

The formula is expressed as:

$$
\mathrm{n}=\frac{N}{1+\left(e^{2}\right) N}
$$

where

$n$ is the sample size to be estimated

$N$ is the definite population of the communities

$e$ is the significance level (0.05).

Using the above formula (equation 1), the sample size was computed to be 400 respondents out of 18,133 households in the study area as indicated in Table 1. Afterward, proportionate sampling technique was used to determine the number of respondents to be drawn from each community based on the projected population of the community. Finally, respondents for the study were randomly selected from a list of households provided by the village heads. The randomization was achieved using random number table generated using Stata version 13.
The respondents were randomly selected from a detailed list of households provided by the village head.

\section{Data collection}

The information regarding the community perceptions on drivers of forest resources' degradation in Falgore Game Reserve was collected from 400 sampled households through household interviews using a structured questionnaire, key informant interviews, and focus group discussions guided by a checklist of questions. The questions asked were related to various causes of NTFPs degradation due to human and natural factors, historical profile of the forest-dependent communities in relation to people-forest interactions during period under investigation.

\section{Satellite data acquisition and image processing}

The Landsat-5 Thematic Mapper (TM), Enhanced Thematic Mapper Plus, and the Operational Land Imager (OLI) and Thermal Infrared Sensor (TIRS) imageries for 1985, 1998, 2005, and 2015 used in this study were retrieved from the United State Geological Survey (USGS) database (http://glovis.usgs.gov/). All the images selected for the analysis were cloud free, and also those captured during the dry season to avoid overestimation of vegetation cover types had 30-m spatial resolution (Table 2).

\section{Forest cover classification}

Due to lack of standardized forest cover classification system for remotely sense data in Nigeria, a classification scheme used by Anderson (1976), Wasonga (2009), and Badamasi et al. (2010) in their various studies for land-use and land-cover change (LULCC) analysis was adopted. The vegetation cover was classified into four major classes based on tree and canopy density as shown in Table 3 .

\section{Data analysis}

The acquired imageries were processed using Arc GIS 10.2 and ERDAS imagine 10 environments. Image pre-

Table 1 Sampling frame and sample size

\begin{tabular}{|c|c|c|c|c|}
\hline S/No. & Local govt areas & Forest adjacent communities & Projected household head population & Sampled population \\
\hline \multirow[t]{3}{*}{1} & \multirow[t]{3}{*}{ Doguwa } & Falgore & 3785 & 83 \\
\hline & & Dogon Kawo & 1178 & 26 \\
\hline & & Sabuwar Kaura & 2090 & 46 \\
\hline \multirow[t]{3}{*}{2} & \multirow[t]{3}{*}{ Sumaila } & Ziria & 1544 & 34 \\
\hline & & Gomo & 2096 & 46 \\
\hline & & Diwa & 1780 & 39 \\
\hline \multirow[t]{3}{*}{3} & \multirow[t]{3}{*}{ Tudun Wada } & Makwasa & 1888 & 42 \\
\hline & & Farurunruwa & 2108 & 47 \\
\hline & & Nata'ala & 1664 & 38 \\
\hline Total & 3 LGAs & 10 & 18,133 & 400 \\
\hline
\end{tabular}


Table 2 Attributes of the used satellite imageries

\begin{tabular}{lllll}
\hline Attributes & 1985 & 1998 & 2005 & 2015 \\
\hline Sensor & Landsat 5 TM LIT & Landsat 5 TM LIT & Landsat 7 ETM + LIT & Landsat 8 OL1/TIRS \\
Path/row & $188 / 52$ & $188 / 52$ & $188 / 52$ & $188 / 52$ \\
Spatial resolution & $30 \mathrm{~m}$ & $30 \mathrm{~m}$ & $30 \mathrm{~m}$ & $30 \mathrm{~m}$ \\
Data of acquisition & $3 / 3 / 1985$ & $277 / 2 / 1998$ & $2 / 3 / 2005$ & $6 / 3 / 2015$ \\
\hline
\end{tabular}

Source: USGS (http://glovis.usgs.gov/)

processing including geometric, atmospheric, and topographic corrections were carried out to ensure spatial and temporal comparability of the datasets (Haj Tahir et al. 2010). The imageries were geo-corrected and georeferenced in order to allow for effective image processing as it is a prerequisite for successful land-use/land-cover change analysis (Tewolde 2011). The 1998 image was used as the reference image for geometrical correction because of its good visual quality. All the bands of the imagery used in the study were resampled to a common pixel value in order to minimize the spatial scale differences between the bands of both datasets.

The iterative self-organizing data analysis (ISODATA) algorithm in ERDAS imagine software (version 9.2) was used to perform an unsupervised classification of 1985, 1998, 2005, and 2015 satellite images. The ISODATA clustering method uses the minimum spectral distance formula to form clusters (ERDAS Inc., 2014). The unsupervised ISODATA classification in this study used 10 classes, confidence threshold of 0.99 , and 200 maximum iterations. The 10 classes were subsequently classified into four major forest cover classes as shown in Table 3.

\section{Rate of change analysis}

The forest cover change analysis was achieved by quantifying the proportion of an area occupied by a particular forest cover type relative to total forest area. This was followed by the determination of relative changes of various forest cover types during the period of the study. To determine the difference between the area of forest cover type at the beginning and at the end of the period under study, the following mathematical formulae by Hansen et al. (2013) was used:

$$
\Delta A=A 2-A 1
$$

where

$$
\Delta A=\text { change area }
$$

$A 1$ and $A 2$ are the area of the target vegetation cover type at date 1 and date 2 .

$$
\mathrm{PAC}=\left(\frac{\Delta A}{T A}\right) \times 100
$$

where $\mathrm{PAC}=$ Percentage area change

$\mathrm{TA}=$ the total area.

$$
\text { Annual rate of change }(\text { ha } / \text { year })=\frac{\Delta A}{N}
$$

where $N$ is a number of years between the beginning and the end of study period.

\section{Change detection matrix}

In order to make a detailed analysis of the dynamics of forest cover change, transition matrices were developed. Transition matrices are tables with symmetric arrays, composed of the forest cover classes from the initial date in one axis and the same classes from the subsequent date in the other (date 1 and date 2). Each cell of the main diagonal of the matrix contains the surface area (ha) of each class of forest cover type that remained unchanged during the time period under consideration, while the remaining cells contain the estimated area of a given forest cover class that changed to a different class during the same time period (Luenberger 1979). Therefore, the gross gain for each land-use and land-cover change (LULCC) category is computed by subtracting the persistence from the column total, while the gross loss is derived by subtracting the persistence from the row total (Pontius Jr and Malizia 2004).

Table 3 Forest cover classes

\begin{tabular}{lll}
\hline S/No. & Land cover category & Description \\
\hline 1 & Dense woodland & Predominated by trees $(>70 \%)$ \\
2 & Moderate woodland & Area with $50-70 \%$ tree cover \\
3 & Stream & Stream and river \\
4 & Open woodland & Areas with moderately scatters trees $(<10-49 \%)$ \\
5 & Very open woodland & Areas with scattered trees $(<10 \%)$ \\
\hline
\end{tabular}

Source: survey by authors, 2015 


\section{Results and discussions}

\section{Forest cover classes}

Figure 2 presents the spatial and temporal pattern of various forest cover types for 1985 to 2015. The spatial extent for forest cover types are shown in Table 4 . The results reveal that moderate woodland was the dominant forest cover type in 1985 and 2005, accounting for about 46 and $57 \%$ of the total forest area, respectively. Open woodland was dominant in 1998 and 2015 covering about 50 and $58 \%$ of the reserve, respectively. Dense woodland occupied the least area that drastically decreased from $17 \%$ in 1985 to $1 \%$ in 2015 . A corresponding decrease in area occupied by moderate woodland from $45 \%$ in 1985 to $29 \%$ in 2015 is an indication that forest cover has been declining in the forest reserve. This reduction can be attributed to uncontrolled collection of non-timber forest products (NTFPs), climate variability, and natural and human-induced forest fires as observed in many part of Africa (Kessy et al. 2016; Chan and Sasaki 2014; and Mayes et al. 2015). The results further reveal that very open woodland formed $14 \%$ of the total forest area of the FGR in 1985 but sharply reduced to 8 and 9\% in 1998 and 2005, respectively. These gains were attributed to forest succession on bared land as well as natural regeneration of trees on sites where trees were cleared for fuelwood and grazing in the reserve.

The classified maps of 1985, 1998, 2005, and 2015 shown in Fig. 2 indicate that dense woodland was predominantly along river Kano tributaries, while very open woodland was mainly found in the northern tip of the reserve where the reserve bordered Tiga artificial Lake. This could be attributed to the fact that when the lake is full, it usually submerges the northern part of the

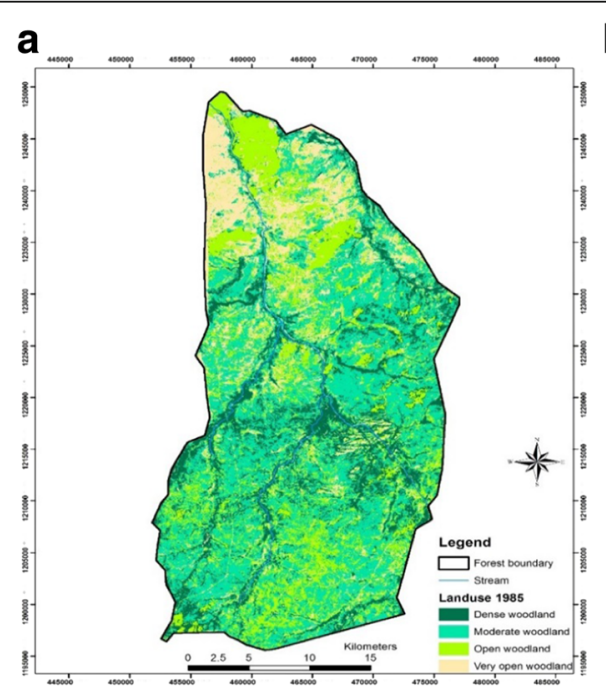

c

b
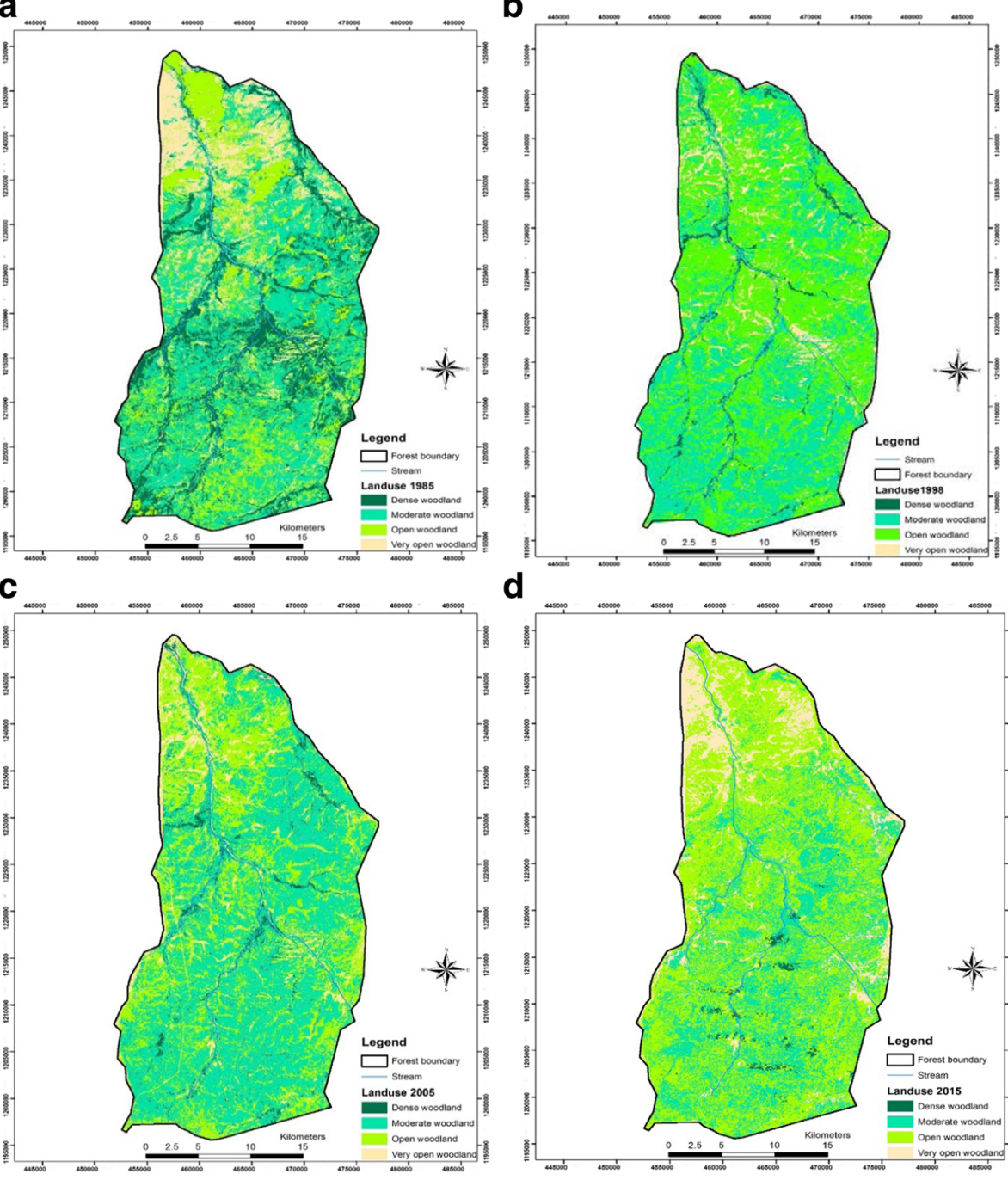

d

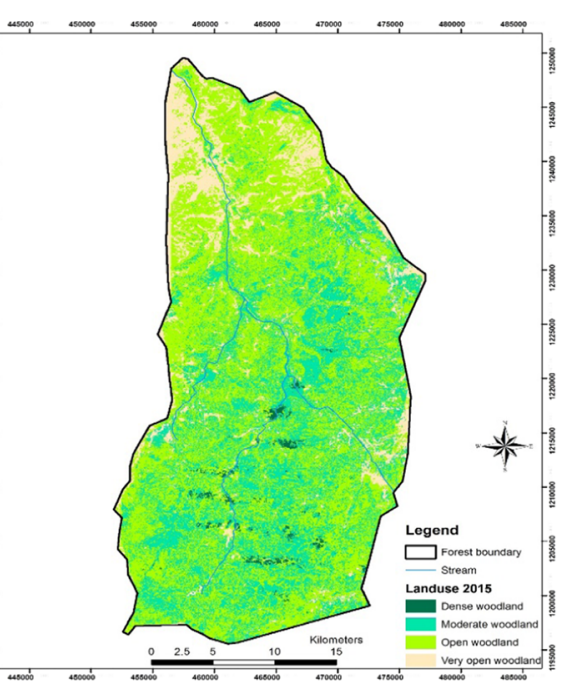

Fig. 2 Forest cover in the Falgore game reserve during 1985 (a); 1998 (b); 2005 (c); and 2015 (d) 
Table 4 Forest cover types in Falgore Game Reserve during 1985 to 2015

\begin{tabular}{lllcr}
\hline Forest cover type & \multicolumn{1}{l}{ Area (ha) } & & & \\
\cline { 2 - 5 } & 1985 & 1998 & 2005 & 2015 \\
\hline Dense woodland & $15,918.5(17)$ & $3127.3(3)$ & $2827(3)$ & $787.41(1)$ \\
Moderate woodland & $41,941.5(46)$ & $34,524.9(38)$ & $53,086.1(57)$ & $26,375.3(29)$ \\
Open woodland & $21,127.3(23)$ & $46,783.6(51)$ & $28,234.6(31)$ & $53,392.7(58)$ \\
Very open woodland & $13,066.1(14)$ & $7617.57(8)$ & $7905.7(9)$ & $11,497.9(12)$ \\
Total & $92,053.4$ & $92,053.4$ & $92,053.4$ & $92,053.4$ \\
\hline
\end{tabular}

Source: survey by authors, 2015. Percentage of forest cover is shown in parentheses

reserve thereby reducing the population densities of the trees in the affected area (Badamasi et al. 2010).

The classified map of 2005 reveals an unprecedented increase in moderate woodland diffusing eastward and southward of the reserve. However, in the classified map of 2015 open woodland had diffused southward with patches found everywhere in the reserve, further implying continuous deforestation in the study area. The decline in dense woodland during 2005-2015 is consistent with an increase in very open woodland from about $9 \%$ in 2005 to $12 \%$ in 2015 . It can also be observed from the classified maps that the reserve suffered its greatest degradation between 1985 and 1998 especially around the northern and eastern part; however, there was a gain in the general trees' densities in 2005.

Figure $2 \mathrm{~d}$ shows that the degradation trend continued and spread across the reserve as very open woodland is found everywhere. These changes in forest cover types during this period signify a high rate of deforestation going on the reserve due to ineffective management strategies. This finding corroborates those of Food and Agriculture Organization (FAO 2001 and FAO 2005) that deforestation rate in Nigeria has increased from $2.38 \%$ per year in the 1990 s to $5.7 \%$ in 2005 .

\section{Extent of forest cover changes during 1985 to 2015}

Table 5 shows the annual average rates of change for the forest cover types during the study period. The results indicate that dense woodland, moderate woodland, and open woodland had higher rate of change compared to the very open woodland during the period under study. For example, between 1985 and 2015, dense woodland, moderate woodland, and very open woodland decreased by $15,131,15,566$ and 1568.2 ha with percentage annual average rates of 3,1 , and $0.4 \%$, respectively. On the other hand, open woodland had increased by $32,265.2$ ha at an annual average rates of about $5 \%$. Open woodland was the most dynamic during the period under study as it increased at an increasing rate, though it declined in 1998. The reasons for the decrease in dense woodland and moderate woodland is partly because these are the areas targeted for commercial timber logging as revealed by the key informants and participants of focus group discussions.

Generally, the observed increase in the extent of forest cover changes during 1985 to 2005 was linked to settlement of the Fulani cattle herders in the reserve. Upon sedentarization, the community fell trees to feed their livestock and construct houses. In addition, the community over relies on forest resources to meet their economic and food needs, especially at times of scarcity occasioned by droughts. As indicated by Yelwa (2008), the FGR serves as safety nets to proximate communities by offering alternative income source and food for households during the off-farming season.

\section{Forest cover transition matrix during $\mathbf{1 9 8 5}$ to 2015}

Table 6 shows the results of transition pattern of various forest cover types in FGR during 1985 to 2015. The diagonal figures in (Table 6A, B, C and D) show the amounts of forest cover type that remained unchanged (persistence) at a given period, while the column "gain" and row "loss" shows the amount of increase or decrease in a particular forest cover type, as well as the trajectories of the conversions (Alo and Pontius 2008). More specifically, the result reveals that out of the $15,918.5$ ha

Table 5 Trends of the extent of forest cover types in Falgore Game Reserve during 1986 to 2015

\begin{tabular}{|c|c|c|c|c|c|c|}
\hline \multirow[t]{2}{*}{ Forest cover type } & \multicolumn{6}{|c|}{ Extent of change (ha (\%)) } \\
\hline & $1985-1998$ & 1998-2005 & $2005-2015$ & $1985-2015$ & Relative change (\%) & Annual rate of change (\%) \\
\hline Dense woodland & $-12,791.2(-13.9)$ & $-300.3(-0.33)$ & $-2039.6(-2.2)$ & $-15,131.1(-16.4)$ & -95 & -3 \\
\hline Moderate woodland & $-7416.6(-8.1)$ & $18,561.2(20.2)$ & $-26,710.8(-29)$ & $-15,566.2(-16.9)$ & -37 & -1 \\
\hline Open woodland & $25,656.3(27.9)$ & $-18,549(-20.2)$ & $25,158.1(27.3)$ & $32,265.42(35.1)$ & 153 & 5.1 \\
\hline Very open woodland & $-5448.5(-5.9)$ & $288.1(0.31)$ & $3592.3(3.9)$ & $-1568.17(-1.7)$ & -12 & -0.4 \\
\hline
\end{tabular}

Source: survey by authors, 2015. Percentage of forest cover change is shown in parentheses 
Table 6 Nature of forest cover change from 1985 to 2015

\begin{tabular}{|c|c|c|c|c|c|c|}
\hline 1985-1998 & (A) & & & & & \\
\hline Cover type & DW & MW & OW & Vow & Total 1985 & Loss \\
\hline DW & 2095.5 & 6972 & 6444 & 407 & $15,918.5$ & 13,823 \\
\hline MW & 689.5 & 19,267 & 20,650 & 1335 & $41,941.5$ & $22,674.5$ \\
\hline OW & 0 & 5640 & 12,907 & 2580.3 & $21,127.3$ & 8220.3 \\
\hline VOW & 342.3 & 2645.9 & 6782.6 & $3,295.3$ & $13,066.1$ & 9770.8 \\
\hline Total 1998 & 3127.3 & $34,524.9$ & 46,784 & 7617.6 & $92,053.4$ & \\
\hline Gain & 1031.8 & $15,257.9$ & 33,877 & 4322.3 & & \\
\hline 1998-2005 & (B) & & & & & \\
\hline Cover type & DW & MW & OW & VOW & Total 1998 & Loss \\
\hline DW & 801.5 & 1977.3 & 154.3 & 194.2 & 3127.3 & 2325.8 \\
\hline MW & 1194.9 & $24,419.7$ & 7225.4 & 1684.9 & $34,524.9$ & $10,105.2$ \\
\hline OW & 775.4 & $24,977.1$ & 17,483 & 3548.4 & $46,783.6$ & $29,300.9$ \\
\hline Vow & 55.2 & 1712 & 3372.2 & $2,478.17$ & 7617.57 & 5139.4 \\
\hline Total 2005 & 2827 & $53,086.1$ & 28,235 & 7905.67 & $92,053.4$ & \\
\hline Gain & 2025.5 & $28,666.4$ & 10,752 & 5427.5 & & \\
\hline $2005-2015$ & (C) & & & & & \\
\hline Cover type & DW & MW & OW & VOW & Total 2005 & Loss \\
\hline DW & 126.7 & 1274.7 & 1338.2 & 87.4 & 2827 & 2700.3 \\
\hline MW & 592.8 & $18,704.4$ & 31,791 & 1997.7 & $53,086.1$ & $34,381.7$ \\
\hline OW & 39.6 & 5371.5 & 17,298 & 5525.3 & $28,234.6$ & $10,936.4$ \\
\hline VOW & 28.3 & 1024.7 & 2965.1 & $3,887.6$ & 7905.7 & 4018.1 \\
\hline Total 2015 & 787.4 & $26,375.3$ & 53,393 & 11,498 & $92,053.4$ & \\
\hline Gain & 660.7 & 7670.9 & 36,095 & 7610.4 & & \\
\hline 1985-2015 & (D) & & & & & \\
\hline Cover type & DW & MW & OW & VOW & Total 1985 & Loss \\
\hline DW & 321 & 6385 & 8555 & 658 & 15,919 & 15,598 \\
\hline MW & 331 & 13,867 & 25,297 & 2447 & 41,942 & 28,075 \\
\hline OW & 110 & 4758 & 13,294 & 2965 & 21,127 & 7833 \\
\hline VOW & 25 & 1366 & 6247 & 5,428 & 13,066 & 7638 \\
\hline Total 2015 & 787 & 26,376 & 53,393 & 11,498 & 92,054 & \\
\hline Gain & 466 & 12,509 & 40,099 & 6070 & & \\
\hline
\end{tabular}

Source: survey by authors, 2015. DW dense woodland, $M W$ moderate woodland, OP open woodland, VOW very open woodland

of dense woodland in 1985, 2095.5 ha remained unchanged, while 6972, 6444, and 407 ha were lost to moderate woodland, open woodland, and very open woodland, respectively. Furthermore, the total dense woodland gain and loss during that period were 1031.8 and 13,823 ha, respectively (Table 6A). These findings corroborate those of Onojeghuo and Blackburn (2011) who reported that Niger Delta region of Nigeria had suffered its biggest deforestation and forest cover transitions between 1998 and 2015 due to uncontrolled fuelwood extraction, timber logging, and oil exploration in the region.

Moderate woodland account for about 34,524.9 ha in 1998 , out of which $24,419.7$ ha remained unchanged while $1194.9,7225.4$, and 1684.9 ha have changed to dense woodland, open woodland, and very open woodland, respectively. Similarly, out of the 13,066.1 ha of very open woodland in 1985,5428 ha remained stable by 2015, while 25, 1366, and 6247 ha changed to dense woodland, moderate woodland, and open woodland, respectively. Very open woodland markedly shrunk from 13,066 ha in 1985 to 11,498 ha in 2015 . Open woodland increased from 21,127 ha in 1985 to 53,393 ha in 2015 at the expense of dense woodland, moderate woodland, and very open woodland, which decline by $8555,25,297$, and 6247 ha in 2015, respectively. These transitions reflect the forest cover dynamics in the reserve, though it is acknowledged that some of these changes were attributed to classification and data errors.

These changes might be due to natural factors (rainfall), biological factors, and a number of anthropogenic factors such as indiscriminate felling of trees to pave way for agriculture, fuelwood, and overgrazing as indicated by the communities during FGDs.

The spatial and temporal patterns of the forest cover transitions are shown in Fig. 3d. It can be observed that between 1985 and 1998, most of the areas under dense woodland found around the bank of river Kano, eastward and southward of the reserve, were replaced by very open woodland and moderate woodland. Between 2005 and 2015, the major transition was the replacement of moderate woodland by open woodland from central to southern parts of the reserve, indicating excessive harvesting of fuelwood, felling of trees for construction, and collection of NTFPs by the local communities living around the forest. The classified maps further indicate that forest resource degradation mostly occurred along river Kano, eastern, northern tip, and southern part of the reserve. This degradation hotspot should therefore be targeted for protection and or restoration if this trend is to be addressed.

\section{Drivers of forest resource degradation as perceived by the communities}

The main drivers of forest resources degradation as perceived by the respondents were forest fire, poor grazing management, expansion of crop cultivation, fuelwood collection, illegal hunting of game animals, and harvesting of medicinal plants (Table 7). Most (60\%) of the households in all the communities indicated that forest fire frequently occurred in the reserve especially during dry season. They further opined that forest fire was mainly caused by game hunters, illegal honey collectors, and the military men deployed to protect the reserve against cattle rustlers and arm robbers along KanoJos highway. This is because both honey collectors and game animal hunters often set fire in order to subdue their target with smoke which most at time results in 


\section{a}

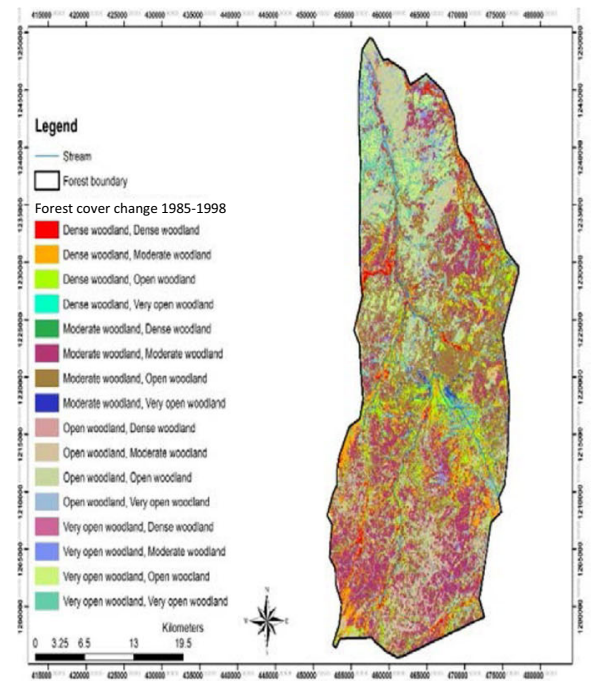

c

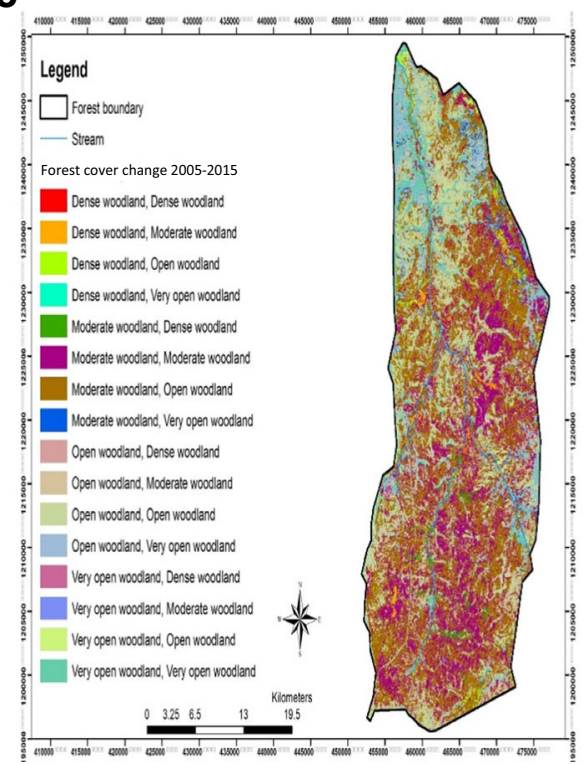

b

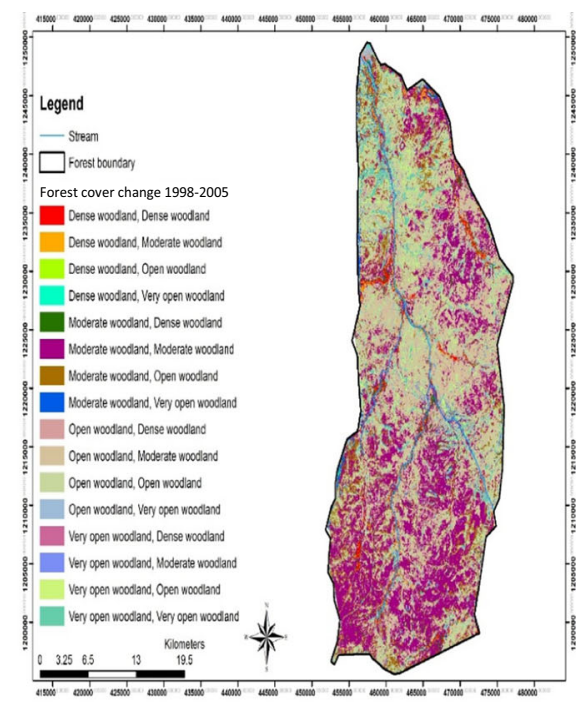

d

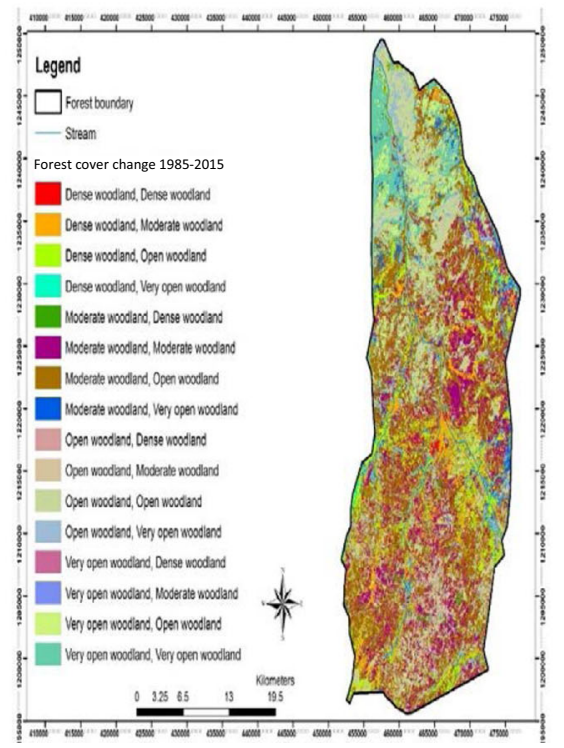

Fig. 3 Forest cover change matrix during 1985 (a); 1998 (b); 2005 (c); and 2015 (d)

destructive fire incidence in the reserve. However, the chisquare test shows no significance difference in the responses from households regarding the effect of forest fire. This finding corroborate those of Kessy et al. (2016) and Mohammed et al. (2013) who observed that humaninduced forest fire was the major causes of forest degradation in REDD+ project villages in Tanzania and National Parks in Nigeria. Majority $(86 \%)$ of the respondents indicated that poor grazing management in the reserve pose serious conservation threats to forest resources in the area. They reported that Fulani herdsmen who illegally settled in the reserve often engage in other destructive activities such as crop cultivation, honey collection, and hunting of wild animals thereby causing deforestation and
NTFPs degradation. The chi-square test of significance of households' perceptions in the different communities showed no significant difference, implying that their responses were similar. This finding support those of Badamasi et al. (2010) who reported that Fulani cattle keepers usually ignite fires in the FGR to clear the vegetation to give way to fresh pasture growth. This further suggests the need for quick measures that would address the illegal settlement and livestock keeping in the reserve to ensure sustainable conservation of the forest.

Expansion of crop cultivation (66\%) especially around the eastern part (Sumaila LGA) of the reserve is one of the key drivers of forest resource degradation in the study area. Nevertheless a reasonable percentage of households from 
Table 7 Community perceptions on anthropogenic causes of forest resources degradation

\begin{tabular}{|c|c|c|c|c|c|}
\hline Drivers & Community & Yes & No & $\mathrm{df}$ & $x^{2}$ \\
\hline \multirow[t]{3}{*}{ Forest fire } & Doguwa & $75(59)$ & $52(41)$ & 2 & $0.895^{\mathrm{NS}}$ \\
\hline & Tudunwada & $87(58)$ & $63(42)$ & & \\
\hline & Sumaila & $78(63)$ & $45(37)$ & & \\
\hline \multirow[t]{3}{*}{ Poor grazing management } & Doguwa & $113(89)$ & $14(11)$ & 2 & $2.719^{\mathrm{NS}}$ \\
\hline & Tudunwada & $131(87)$ & $19(13)$ & & \\
\hline & Sumaila & $101(82)$ & $45(37)$ & & \\
\hline \multirow[t]{3}{*}{ Expansion of crop cultivation } & Doguwa & $100(79)$ & $27(21)$ & 2 & $13.102^{* * *}$ \\
\hline & Tudunwada & $92(61)$ & $58(39)$ & & \\
\hline & Sumaila & $73(59)$ & $50(41)$ & & \\
\hline \multirow[t]{3}{*}{ Fuelwood collection } & Doguwa & $116(91)$ & $11(9)$ & 2 & $1.468^{\mathrm{NS}}$ \\
\hline & Tudunwada & $134(89)$ & $16(11)$ & & \\
\hline & Sumaila & $115(93)$ & $8(7)$ & & \\
\hline \multirow[t]{3}{*}{ Illegal hunting of game animals } & Doguwa & $42(33)$ & $85(67)$ & 2 & $0.421^{\mathrm{NS}}$ \\
\hline & Tudunwada & $47(31)$ & $103(69)$ & & \\
\hline & Sumaila & $36(29)$ & $87(71)$ & & \\
\hline \multirow[t]{3}{*}{ Harvesting of medicinal plants } & Doguwa & $89(70)$ & $38(30)$ & 2 & $5.519^{* *}$ \\
\hline & Tudunwada & $85(57)$ & $65(43)$ & & \\
\hline & Sumaila & $80(65)$ & $43(35)$ & & \\
\hline
\end{tabular}

Source: survey by authors, 2015 ; Statistical significance level: ${ }^{* *} 1 \%,{ }^{* * 5 \%,}{ }^{\text {NS}}$ Non-signicant difference

Sumaila (41\%) and Tudunwada (39\%) were opposing such claim, this was however confirmed by the chi-square result which indicated significance $(P>0.01)$ difference in the community perceptions regarding people encroachment into the reserve due to agricultural activities. These results agree with those of Arnold and Perez (2001) and FAO (2007) that commercial agricultural expansion account for two-third of forest resource degradation in Latin America while subsistence agriculture expansion accounts for onethird of deforestation in tropical and sub-tropical Africa and Asia. Majority (91\%) of the households interviewed in all the communities reported that illegal collection of fuelwood for subsistence and income generation which most at times involved cutting down of trees was the major cause of forest degradation in the FGR. Non-significant difference observed in the chi-square test indicates high degree of agreement among the respondents (Table 7).

This is because fuelwood as reported by May-Tobin (2011) and Ogunsawa and Ajala (2002) is the primary source of domestic cooking energy for rural and urban households, as well as some industrial users in developing countries such as Nigeria. The authors also found that the high cost of alternative cooking energy largely contributed to indiscriminate cutting down of trees thereby causing forest degradations.

Overall, only $31 \%$ of the interviewed households in all the communities considered illegal hunting of game animals as serious threat to conservation although it could have far reaching impacts considering that most of the illegal hunters also engaged in cutting down of trees to prepare animal traps or built temporary settlements in the reserve. This opinion, however, shows no statistical difference among the communities in the study area. Harvesting of medicinal plants was also perceived by the communities as one of the human-induced cause of forest resource degradation in FGR. About 70 and $65 \%$ of the interviewed households from Doguwa and Sumaila were of that opinion, while slightly less than half of the respondents from Tudunwada opined that medicinal plants extraction cause no harm to the forest resource. The chi-square test showed that there were significant $(P>0.05)$ differences in the responses of the interviewed households from the various communities. As indicated by Belcher and Schreckenberg (2007); Meyfroidt and Lambin (2008); Rodríguez-Vicente and Marey-Pérez (2009) and Ndoye et al. (2016), uncontrolled extraction of trees roots and bark in forestlands often leads to the death of the affected tree thereby reducing the resource base as well as negatively impacting on the ecosystem service provisioning of the forest.

\section{Discussion}

Spatially, the large part of the forestlands in FGR was seriously degraded, implying that deforestation is evident and remain the major problem in the study area. Forest loss was predominantly in the northern, central, and eastern part of the reserve. This was essentially as a result of increased pressure on forest resource by locals, through 
excessive NTFPs' extraction such as fuelwood, fodder, medicinal plants, and illegal hunting of game animals. Consequently, between 1985 and 1998, dense woodland had reduced by about $80 \%$ indicating the highest decreased among the various forest cover types under the study periods. Excessive drought and famine experienced in the state and Nigeria in general during this period which raises the demand for agricultural land, fuelwood, and wild foods explains the majority of this forest loss. This is because during such periods, the households intensified their activities for NTFPs' collection such as charcoal burning, medicinal herbs extraction, and timber logging in order to supplement their households' income (Tudunwada 2012). In contrary, open woodland had recorded the highest gain (153\%) between 1985 and 2015 at an annual average rate of about $5 \%$. The instability in the trends of forest cover loss or gain displayed by moderate woodland, open woodland, and very open woodland reflect the physical and bio-physical processes going in the forest. For instance, the decrease in very open woodland indicates the biological ability of some of the tree species to regenerate after some times. However, the unprecedented degradation of dense woodland and moderate woodland could be explained by the vigour nature of the tree species which favours exploitation by local people for timber and charcoal making for household used and income generation. Though there was dynamism in the nature of forest cover loss or gain in FGR, these results clearly indicate lack of stability in forest cover type as well as inefficiency in management strategies employed in the reserve.

However, the classified forest cover maps (Fig. 2) indicated that the northern, central, and eastern parts of the reserve were the hotspot of deforestation hence requires immediate attention if the rate of forest resource degradation is to be reduced. These findings reflect the extent of forest resources degradation in those parts of the forest due to anthropogenic adverse influences in addition to natural factors. For example, the northern part of the reserve is usually affected by Tiga Lake which when full usually submerge the northern tip of the forest as the water from the lake flowed through river Kano which dissected the reserve. The degradation in central and eastern parts was mainly due to local people pressure on the available resource in the reserve. For instance, the communities in the eastern part of the forest were predominantly inhabited by Fulani people who were mostly cattle keepers, hunters, and honey collectors. The Kano state policy of 1982 which allows cattle keepers to graze in the reserve leads to the illegal settlement of many herdsmen in the forest who often engaged in cutting down of trees to pave way for pasture growth, crop cultivation, and their temporary settlements.

About 70 to $80 \%$ of forest resources degradation recorded in Nigeria were due to human-induced factors
(Osemeobo 1988). The findings of this study also confirmed that indiscriminate felling of trees for fuelwood, unsustainable harvesting of medicinal plants, forest fire, expansion of crop cultivation, poor grazing management, and illegal hunting of game animals were perceived by most of the households as the root causes of forest degradation in the study area. As reported by the respondents during FGDs and key informants interview, majority of the households living in the communities proximate to FGR derived between 20 and $60 \%$ of their total households' income from sale and consumption of NTFPs. This further indicates the extent of community dependence on the forest resource in the study area. Forest fire which was believed to be caused by men of military personnel, illegal honey collectors, Fulani herdsmen, and hunters was negatively affecting the forest cover in FGR as perceived by the respondents; this was also found in the report of Yelwa (2008), Badamasi et al. (2010), and Tudunwada (2012) that forest fire which often used by locals in their quest for forest resource exploitation was detrimental to ecosystem service provisioning of FGR. In support of this argument available data from 118 countries representing $65 \%$ of the global forest area, an average of 19.8 million ha or $1 \%$ of all forests were reported to be significantly affected each year by forest fires (Anonymous 2010). The destruction of cattle routes, grazing reserves, and water points for livestock across the country lead to the illegal inversion of the states' protected areas by cattle keepers in most part of Nigeria which in turn result in forest degradation due to poor grazing management. This was however confirmed from the results of satellite imageries which showed increased number of bare land patches in the forest. However, increased demand for food in Nigeria due to increase in human population is directly linked to the encroachment of the protected areas as a result of expansion of farmlands. As reported by the participants of FGDs and confirmed by the authors, there were presence of farmlands beyond the forest cutline especially at the central and eastern parts of the reserve. In addition, the increase in the annual average temperature of Nigeria to $1.1{ }^{\circ} \mathrm{C}$ above the world average $\left(0.74{ }^{\circ} \mathrm{C}\right)$ and the decrease in average rainfall by about $81 \mathrm{~mm}$ (Ademola and Bamigboye 2016) were directly linked to forest ecosystem degradation. Savannah woodland ecosystem like FGR is more likely to be negatively affected by the changes in rainfall pattern as it may probably affect the density of tree plants, as well as their biological ability to regenerate naturally.

\section{Conclusions}

It is evident that forest resources degradation has taken place in FGR at a very high rate between 1985 and 2015. Relatively, the percentage change of various forest cover 
types is higher during 2005 to 2015 than during 1985 to 1998 and 1998 to 2005. However, open woodland and dense woodland recorded the highest annual rate of change of 3 and 5\% during 1985 to 2015, respectively. The gross loss was highest for moderate woodland followed by dense woodland, while the gross gain was highest for open woodland followed by very open woodland during the period under study. The prominent transitions of forest cover type during period under study are dense woodland to moderate woodland, moderate woodland to open woodland, and very open woodland to dense woodland. These forest cover transitions are largely attributed to intensification of anthropogenic activities in and around the forest. The key hotspots of forest resource degradation in the study area coincided with the areas where excessive fuelwood collection, timber logging, and poor grazing management were reported in the forest reserve (northern tip, central, and eastern parts). Overall, these findings suggest that FGR is currently faced with forest resource degradation, a problem attributed to excessive fuelwood collection, poor grazing management, expansion of crop cultivation, forest fire, harvesting of medicinal herbs, and illegal hunting of game animals. It is therefore clear that the spatial distributions and changes in forests cover types could offer interesting insights into more local-scale processes and activities that are detrimental to the ecosystem service provisioning of the FGR.

Based on the findings of this study, the following recommendations were made: There is an urgent need for stakeholders to direct efforts towards developing conservation strategies that would ensure effective and efficient management of forest resources in Falgore Game Reserve. Public enlightenment and awareness campaign about the negative consequences of forest resource degradation on natural environment and human welfare is indispensable towards building the right behaviour and political goodwill among the communities proximate to FGR, this would go a long way in ensuring the enforcement of conservation policies in the area. Greater efforts should be directed towards restoration of degraded areas especially around the northern tip of the reserve; use of biogas as an alternative cooking energy should be promoted in the study area. This would reduce overreliance on fuelwood by the local people thereby reducing the rate of destruction of natural vegetation in the area. Local people should also be educated on sustainable and ecological procedure of harvesting medicinal herbs while encouraging them to domesticate the most commonly used tree-plants for traditional medicines to help reduced pressure on the wild stock. Lastly, establishment of a forest buffer zone around FGR is necessary in order to arrest the problem of encroachment into the reserve due to agricultural expansion.

\section{Abbreviations}

GIS: Geographic information system; LGA: Local government area;

LULCC: Land-use and land-cover change; NTFPS: Non-timber forest products; USGS: United State Geological Survey

\section{Acknowledgements}

Study and research funding provided by Carnegie foundation through RUFORUM is immensely appreciated.

\section{Authors' contributions}

SMS developed the concept, carried out the field data collection and data analysis, and drafted the manuscript. WVO, JSM, and YEA made comments on the manuscript. All authors read, revised, and approved the manuscript.

\section{Competing interests}

The authors declare that they have no competing interests.

Received: 13 November 2016 Accepted: 16 February 2017 Published online: 16 March 2017

\section{References}

Ademola EO, Bamigboye FO (2016) Woes and Ways Out of Carbon Footprint Implications: A Review. Proceedings of the iSTEAMS Multidisciplinary CrossBorder Conference University of Professional Studies, Accra

Akinbami JF, Salami AT, Siyanbola WO (2003) An integrated strategy for sustainable forest-energy-environment interactions in Nigeria. J Environ Manage 69:115-128

Alo CA, Pontius RG (2008) Identifying systematic land-cover transitions using remote sensing and GIS: the fate of forests inside and outside protected areas of Southwestern Ghana. Environ Plann B Plann Des 35:280-295

Anderson JR (1976) A land use and land cover classification system for use with remote sensor data (Vol. 964). US Government Printing Office. https://books. google.co.ke/books?hl=en\&lr=\&id=dE-ToP4UpSIC\&oi=fnd\&pg=PA1\&dq= Anderson+JR+(1976)+A+land+use+and+land+cover+classification+system + for+use+with + remote+sensor+data\&ots $=s W q 01 Z 4 i 9 C \& s i g=$ eDZki6oFjIXkBUgKIBv_e5VkNiE\&redir_esc=y\#v=onepage\&q= Anderson\%20JR\%20

Anonymous (2010) Global Forest Resources Assessment, 2010-Main Report. FAO Forestry Paper 163. Rome; 340.

Arnold JM, Pérez MR (2001) Can non-timber forest products match tropical forest conservation and development objectives? Ecol Econ 39:437-447

Badamasi MM, Yelwa SA, AbdulRahim MA, Noma SS (2010) NDVI threshold classification and change detection of vegetation cover at the Falgore Game Reserve in Kano State, Nigeria. Sokoto J Soc Sci 2:174-194

Belcher B, Schreckenberg K (2007) Commercialization of non-timber forest products: A reality check. Deve Policy Rev 25:355-377

BirdLife International (2007) BirdLife's online World Bird Database: the site for bird conservation. http://www.birdlife.org.

Chan S, Sasaki N (2014) Assessment of drivers of deforestation and forest degradation in phnom tbeng forest based on socio-economic surveys. J Environ Prot 5:1641

Diouf A, Lambin EF (2001) Monitoring land-cover changes in semi-arid regions: remote sensing data and field observations in the Ferlo, Senegal. J Arid Environ 48:129-148

Dunjó G, Pardini G, Gispert M (2003) Land use change effects on abandoned terraced soils in a Mediterranean catchment, NE Spain. Catena Suppl 52:2337

FAO (2001) Global Forest Resources Assessment 2000, FAO Forestry Paper 140

FAO (2005) State of the World's Forests 2005. FAO, Rome

FAO (2007) State of the World's Forests 2007. FAO, Rome

FAO (2010) Global Forest Resources Assessment 2010 Country Report Indonesia Forest Resource Assessment (FRA) 2010/095. UNFAO, Rome

FRN (2010) Fourth National Biodiversity Report to the United Nation. Prospect and Constraints in achieving the goals and target of CBD. https://www.cbd. int/doc/world/ng/ngnr-04-en.pdf.

Glenn D (1992) Determining sample size. Gainesville: University of Florida Cooperative Extension Service, Institute of Food and Agriculture Sciences, EDIS.

Green JM, Larrosa C, Burgess ND, Balmford A, Johnston A, Mbilinyi BP, Platts PJ, Coad L (2013) Deforestation in an African biodiversity hotspot: Extent, variation and the effectiveness of protected areas. Biol Conserv 164:62-72 
Haj Tahir ME, Kääb A, Xu CY (2010) Identification and mapping of soil erosion areas in the Blue Nile, Eastern Sudan using multispectral ASTER and MODIS satellite data and the SRTM elevation model. Hydrol and Earth Syst SC 14: $1167-1178$

Hansen MC, Potapov PV, Moore R, Hancher M, Turubanova SA, Tyukavina A, Thau D, Stehman SV, Goetz SJ, Loveland TR, Kommareddy A (2013) High-resolution global maps of 21st-century forest cover change. Science 342:850-853

Heistermann M, Müller C, Ronneberger K (2006) Land in sight? Achievements, deficits and potentials of continental to global scale land-use modeling. Agric Ecosyst Environ 114:141-158

Kessy JF, Nsokko E, Kaswamila A, Kimaro F (2016) Analysis of Drivers and Agents of Deforestation and Forest Degradation in Masito Forests, Kigoma, Tanzania. Int j Asian Soc Sci 6:93-107

KNARDA (2006) Mission, vision and achievements of the special mass food production programme, Kano State. Kano state Ministry of agriculture and rural development publication No. 31. 2-10

KNARDA (2015) Kano State Agricultural household Survey for subsidies input distribution. Crop productivity records book. Kano State Agricultural and Rural Development Authority, Bulletin [10] 2-11-2015.

Lambin EF, Goyvaerts K, Petit C (2003) Remotely-sensed indicators of burning efficiency of savannah and forest fires. Int J Remote Sens 24:3105-3118

Laurin GV, Liesenberg V, Chen Q, Guerriero L, Del Frate F, Bartolini A, Valentini R (2013) Optical and SAR sensor synergies for forest and land cover mapping in a tropical site in West Africa. Int J Appl Earth Obs and Geoinf 21:7-16

Lepers E, Lambin EF, Janetos AC, DeFries R, Achard F, Ramankutty N, Scholes RJ (2005) A synthesis of information on rapid land-cover change for the period 1981-2000. Bioscience 55:115-124

Liu Y, Fu B, Lü Y, Wang Z, Gao G (2012) Hydrological responses and soil erosion potential of abandoned cropland in the Loess Plateau, China. Geomorphology 138:404-414

Lu D, Moran E, Batistella M (2003) Linear mixture model applied to Amazonian vegetation classification. Remote Sens Environ 87:456-469

Luenberger DG (1979) Introduction to dynamic systems theory, models, and applications. Wiley, New York

Mayes MT, Mustard JF, Melillo JM (2015) Forest cover change in Miombo Woodlands: modeling land cover of African dry tropical forests with linear spectral mixture analysis. Remote Sens Environ 165:203-215

May-Tobin C (2011) Wood for fuel. In: Boucher D, Elias P, Lininger K, May-Tobin C, Roquemore S, Saxon E (eds) The Root of the Problem: What's Driving Tropical Deforestation Today? Union of Concerned Scientists, USA, pp 79-87

MEA (2005) Ecosystems and human well-being: synthesis. Island, Washington, DC. http://www.millenniumassessment.org/documents/document.356.aspx.pdf

Meduna AJ, Ogunjinmi AA, Onadeko SA (2009) Biodiversity Conservation Problems and their Implications on Ecotourism in Kainji Lake National Park, Nigeria. J Sustainable Dev Afr 4:59-73

Melillo JM, Steudler PA, Aber JD, Newkirk K, Lux H, Bowles FP, Catricala C, Magill A, Ahrens T, Morrisseau S (2002) Soil warming and carbon-cycle feedbacks to the climate system. Science 298:2173-2176

Meyfroidt P, Lambin EF (2008) The causes of the reforestation in Vietnam. Land Use Policy 25:182-197

Mohammed SO, Gajere EN, Eguaroje EO, Shaba H, Ogbole JO, Mangut YS, Kolawole IS (2013) Spatio-temporal analysis of the national parks in Nigeria using geographic information system. IFE J Sci 15:159-166

Mwita E, Menz G, Misana S, Becker M, Kisanga D, Boehme B (2013) Mapping small wetlands of Kenya and Tanzania using remote sensing techniques. Int J Appl Earth Obs and Geoinf 21:173-183

Ndoye O, Pérez MR, Eyebe A (2016) The markets of non-timber forest products in the humid forest zone of Cameroon. Overseas Development Institute, London

Ogunsawa OY, Ajala OO (2002) Firewood crises in Lagos- implication on the suburban and rural ecosysyem management. In: Abu JE, Oni PO, Popoola L (eds) Proceeding of the 28th annual conference of Forestry Association of Nigeria at Akure, Ondo State. Nov. 4th - 8th., pp 257-264

Olofin EA (2000) Environmental Hazards and Sustainable Development in Northern Nigeria. In: Falola JA, Ahmed K, Liman MA, Maiwada A (eds) Issues in Land Administration and Development in Northern Nigeria. Department of Geography, Bayero University, Kano, Nigeria, pp 207-220

Onojeghuo AO, Blackburn GA (2011) Forest transition in an ecologically important region: patterns and causes for landscape dynamics in the Niger Delta. Ecol Indic 11:1437-1446

Osemeobo GJ (1988) The human causes of forest depletion in Nigeria. Environ Conserv 15(01):17-28
Oseni JO (2007) Economic analysis of mushroom marketing as a copping strategy for poverty reduction in Ondo State, Nigeria. In: 8th African Crop Science Society Conference, El-Minia, Egypt, 27-31., pp 27-31, October 2007 Egypt, pp. 1255-1260

Overmars KP, Verburg PH (2005) Analysis of land use drivers at the watershed and household level: Linking two paradigms at the Philippine forest fringe. Int J Geogr Inf Sci 19:125-152

Peluso NL (1995) Whose woods are these? Counter-mapping forest territories in Kalimantan, Indonesia. Antipode 27:383-406

Pontius RG Jr, Malizia NR (2004) Effect of category aggregation on map comparison. In: International Conference on Geographic Information Science. Springer Berlin Heidelberg; 251-268

Potter C, Klooster S, Huete A, Genovese V (2007) Terrestrial carbon sinks for the United States predicted from MODIS satellite data and ecosystem modeling. Earth Interact 11:1-21

Redo D, Bass JJ, Millington AC (2009) Forest dynamics and the importance of place in western Honduras. Appl Geogr 29:91-110

Rodríguez-Vicente V, Marey-Pérez MF (2009) Land-use and land-base patterns in non-industrial private forests: Factors affecting forest management in Northern Spain. Forest Policy Econ 11:475-490

Satake A, Rudel TK (2007) Modeling the forest transition: forest scarcity and ecosystem service hypotheses. Ecol Appl 17:2024-2036

Shalaby AA, Ali RR, Gad A (2012) Urban sprawl impact assessment on the agricultural land in Egypt using remote sensing and GIS: a case study, Qalubiya Governorate. J Land Use Sci 7:261-273

Tewolde MG, Cabral P (2011) Urban sprawl analysis and modeling in Asmara, Eritrea. Rem Sens 3:2148-2165

Tsegaye D, Moe SR, Vedeld P, Aynekulu E (2010) Land-use/cover dynamics in Northern Afar rangelands, Ethiopia. Agric Ecosyst Environ 139:174-180

Tudunwada IY (2012) Vegetation change detection due to anthropogenic activities in Falgore Game Reserve, Kano, Nigeria, using GIS and Remote Sensing The International Conference Geotunis 6th Session 26th - 30th March 2012

USAID/Nigeria (2008) Nigeria Biodiversity and Tropical forestry assessment: Maximizing Agricultural Revenue in Key Enterprises (Markets). Chemonics International Inc.

Usman BA, Adefalu LL (2010) Nigerian forestry, wildlife and protected areas: Status report. Biodiversity 11:54-62

Wasonga VO (2009) Linkages between land-use, land degradation and poverty in semiarid rangelands of Kenya: The case of Baringo district (Doctoral dissertation, University of Nairobi, Department of agriculture)

WCS (2010) Nigeria. World Conservation Society (WCS). www.wsc.org > where we work $>$ Africa.

Yang YG, Fox J, Yang X (2007) Forest transition, its causes and environmental consequences: empirical evidence from Yunnan of Southwest China. Trop Ecol 48:137

Yelwa SA (2008) Broad scale Vegetation Change Assessment across Nigeria from Coarse Spatial and High Temporal Resolution, A VHRR Data. Cuvillier Verlag, Gottingen, p 350

\section{Submit your manuscript to a SpringerOpen ${ }^{\odot}$ journal and benefit from:}

- Convenient online submission

- Rigorous peer review

- Immediate publication on acceptance

- Open access: articles freely available online

- High visibility within the field

- Retaining the copyright to your article

Submit your next manuscript at $>$ springeropen.com 